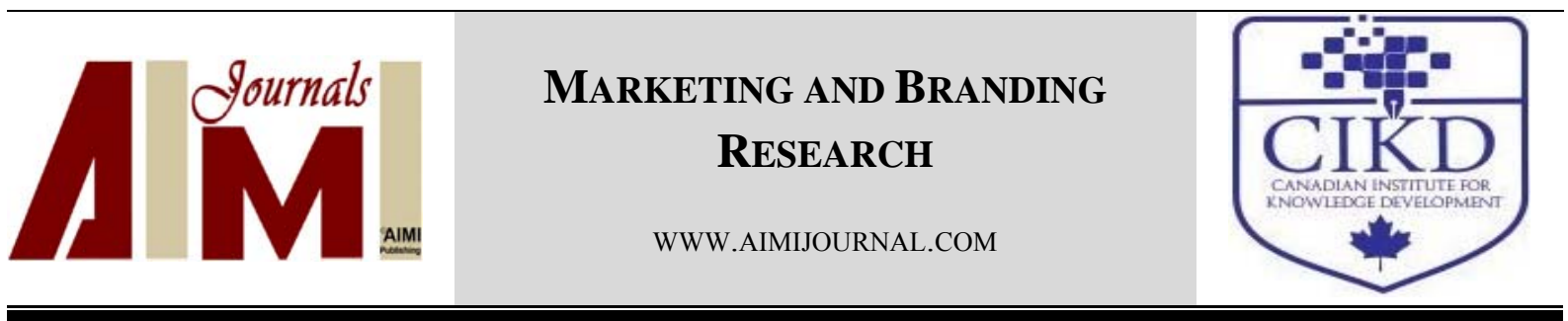

\title{
Perception of Advertising and Expectations of Advertising in terms of Gender Differences
}

\author{
Zuzana Birknerová, Miroslav Frankovský, Lucia Zbihlejová*, Valéria Parová
}

Department of Managerial Psychology, Faculty of Management, University of Prešov in Prešov, Slovakia

\begin{tabular}{|c|c|}
\hline & ABSTRACT \\
\hline $\begin{array}{l}\text { Keywords: } \\
\text { Gender, Advertising, } \\
\text { Perception of Advertising, } \\
\text { Expectations of Advertising }\end{array}$ & $\begin{array}{l}\text { The aim of this paper is to specify the links between expectations of advertising and } \\
\text { perception of advertising according to the gender differences. The fact that individuals } \\
\text { create their subjective cognitive image of these advertisement attributes serves as a basis } \\
\text { for the conceptualization of this paper. The data were collected from two research }\end{array}$ \\
\hline $\begin{array}{l}\text { Received } \\
19 \text { October } 2017\end{array}$ & $\begin{array}{l}\text { samples, } 99 \text { respondents ( } 58 \text { women and } 41 \text { men) and } 206 \text { respondents ( } 113 \text { women and } \\
93 \text { men). The analyses, conducted in two research stages, indicated significant }\end{array}$ \\
\hline $\begin{array}{l}\text { Received in revised form } \\
\text { 06 June } 2018\end{array}$ & $\begin{array}{l}\text { correlations between the selected attributes of expectations of advertising and the factors } \\
\text { of subjective perception of advertising. The results also revealed an existence of }\end{array}$ \\
\hline $\begin{array}{l}\text { Accepted } \\
\text { 09 June } 2018\end{array}$ & $\begin{array}{l}\text { significant differences in perception of advertising and expectations of advertising } \\
\text { between men and women. Women paid more attention to the music and visuals of the }\end{array}$ \\
\hline $\begin{array}{l}\text { Correspondence: } \\
\text { lucia.zbihlejova@smail.unip } \\
\text { o.sk }\end{array}$ & $\begin{array}{l}\text { advertisement and appreciate the humorous aspects in advertising. They also had greater } \\
\text { expectations of advertising - they expect it to be memorable, informative, intelligent, } \\
\text { genuine and visually stunning. }\end{array}$ \\
\hline
\end{tabular}

CAIMI Journals

\section{Introduction}

Advertising is frequently found within various marketing activities mostly related to the supply of goods and services (Bačík, Fedorko, \& Bušová, 2012). However, advertising also occurs when it comes to thinking about people and forming ethical, moral and value orientations. In all contexts, advertising has an influential character. The influence can be interpreted on a vast continuum from nonviolent, inanimate action to intense manipulation of 
non-respecting interests, needs, and other factors that are related to profit, and benefit to the recipients of advertising.

Advertising is today's phenomenon (Lelková \& Lorincová, 2015), surrounding us from every side. It represents a very simple and effective way of visualization which has a strong effect not only on our consciousness but also on our subconscious and works, even if we do not follow the ad, we perceive it. Therefore, the aspect of manipulation in advertising is one of the most important areas of attention in the context of advertising research.

Gender role, gender identity and gender stereotypes create a set of illusions about how women and men in a particular culture and a social environment should behave, express themselves, what they should wear, how they should think and, therefore, what exactly they expect of advertising and how they perceive it. The links between gender and advertising may be analyzed also from the viewpoint of defining gender as a process and characteristics of an individual person (Wharton, 2012).

One of the first authors to use the term "gender" was Oakley (1972), who perceives it as a social and cultural construct as opposed to the biological term "sex". A dominant position in the context of gender is taken by the cultural, political and social conditions of a particular society. In this sense, Connell (2002) claims that the issue of gender has a key dimension in personal life, social relations and culture but at the same time it is a topic which carries along certain prejudice, ideologies, myths and disinformation.

Krook and Childs (2010) briefly describe that sex is exclusively about the biological differences on the basis of which human beings can be categorized into men and women. Gender refers to the social meanings given in relation to the gender in question. Gender points to differences between men and women and deals with the development of gender identities.

Cviková, Debrecínová and Kobová (2007) highlight gender as "social" or "cultural". Gender is attributed to social roles, prejudices, behaviors, ratings and stereotypes, social construction and ideas about what is right or wrong for a man and woman. Historically, it is changing and has different forms within individual cultures but it is also intercultural. It is transmitted and reproduced with the process of social learning.

The following study aims to enrich the area of knowledge of the advertising effects management. The attention is paid to the perception of advertising and expectations of advertising with an emphasis on the gender context. Interconnections between the expectations of advertising and the perception of advertising are specified in two research stages, highlighting the differences between men and women in terms of assessment of expectations of advertising and advertising perception factors.

\section{Advertising and Gender}

There are a large number of definitions of advertising. The basic attributes of advertising were characterized by Stanton (1984) as a presentation which has an audio or visual form, is paid, impersonal, promoting a product, service or an idea. This presentation occurs most frequently via mass media (Bovée \& Arens, 1992).

Advertising is also a form of mental influence that leads to voluntary acceptance, selffulfillment, and pursuit of the goal (Seyffert, 1966). When we look at the definition of advertising outlined by Vysekalová and Komárková (2012), we see that advertising is defined 
as a commercial communication, being part of a marketing mix so-called "4Ps". Reifová and Kolektiv (2004) state that advertising is a specific tool for influencing the opinion-creating, purchasing, moral and aesthetic values. There is a high chance that advertising will gradually start to transform and use more and more communication tools. Toscani (1996) examined advertising in today's society, and even compares it to the "bruised line", and concluded that the ads are selling just a fake feel of happiness rather than products.

Barker (2006) argues that advertising has become an integral part of the culture and its effects are re-transmitted to shape the culture itself. It extends to all subsystems of the social and cultural space and is echoed even in those parts of the social structure which are seemingly unrelated to it. Such approach represents the concept of broader understanding of advertising with its impact on values and norms of the society.

Advertising may also be perceived as one of the most common ways of influencing by means of the semantic transposition to strengthen the sensory-imaginative and the emotionalcognitive impression (Lelková \& Lorincová, 2015).

Subjective creation of the image of advertising relates to several areas of knowledge that are represented by constructs of cognitive schemas, irrational beliefs, contra-fact thinking, the Dunning-Kruger effect, which arises from an erroneous self-esteem and others (Beck, Davis, \& Freeman, 2007; David, Lynn, \& Ellis 2010; Istenik 2011; Mandel, Hilton, \& Catellani, 2005). In connection to the subjective perception of advertising, it is necessary to emphasize the role of emotions that can significantly affect individual creation of the mental advertising image. Abrams and Keren (1997) state that emotions, particularly in terms of intensity and duration, strongly influence the subjective mental image of reality.

Another important factor associated with the image of advertising can be specified in terms of expectations of advertising. According to Newell and Simon (1972), creation of this image sometimes deviates from the criteria of objective rationality, is tinged with emotion and uses various schemes.

Musical and visual processing, humor, fear, the element of surprise, erotica and others may act as peripheral ways and signs and thus affect individuals' purchasing behavior. The above-mentioned factors of perception of advertising are complemented by expectation that the ad will be engaging, truthful, funny, easy to understand, but also credible, informative and intelligent.

The gender context may also be considered in various ways such as perception of the surrounding world without excluding the advertising effects. Gender specifics in the perception of advertising are manifested in products and services as male and female ones (Owolabi, 2005). Several studies (e.g. Gail \& Humez, 2003; Lindner, 2004; Renzetti, Curran, \& Maier, 2012; Štefko, Fedorko, \& Bačík, 2015) suggest that ads are often intertwined by gender stereotypes. Stereotypical roles in advertising often reinforce the gender-stereotypical attitudes of the society. McKay and Covell (1997) found that gender stereotypes in advertising strengthen and reproduce the prevailing myths about gender differences.

Eckert and McConnell-Ginet (2003) add that the questions about the issue of gender are discussed almost in every scientific discipline which deals with human behavior, cognition, society and culture. Individually, people become gender-typical, they continually adapt certain characteristics, roles and behavior desired in women and men of a particular culture, 
which is manifested for example in their decision-making (Suhányi \& Suhányiová, 2014), as well as in relation to perception of advertising and expectations of advertising.

\section{Method}

The main objective of the research was to examine the advertising effects management by means of observing the perception of advertising and the expectations of advertising in relation to gender. The research was conducted in two stages, each using an individual research sample.

The first research sample consisted of 99 respondents, of which 58 were women $(58.6 \%)$ and 41 were men $(41.4 \%)$. The average age of the respondents participating in the first research stage was 27.84 years. The minimum age was 14 years; the maximum age was 60 years. The research methodology used to conduct the first research stage was an original Ad Perception Questionnaire (APQ), which consists of 24 closed items evaluated on a 5-point Likert response scale $(1=$ definitely not, $2=$ no, $3=$ I cannot judge, $4=$ yes, $5=$ definitely yes). The questionnaire identifies advertising at a general level and includes items that track the emotional, cognitive and behavioral aspects of advertising perception.

The second research sample consisted of 206 respondents aged between 18 and 83 years $(M=31.22$ years, $S D=16.08)$, out of which 93 were men $(45.1 \%)$ and 113 were women (54.9\%). The second research stage was conducted by means of two original scales:

1. original Expectations of Advertising (EoA) scale - contains 11 items (true, funny, understandable, credible, memorable, informative, unobtrusive, intelligent, genuine, visually stunning, artistic; $\alpha=.91$ )

2. original Subjective Perception of Advertising (SPoA) scale - contains 5 items (good slogan, good music, good visuals, good humor, the element of surprise; $\alpha=.88$ )

The respondents had a choice of answers on a 6-point scale, ranging from "definitely not" to "definitely yes".

The obtained data were evaluated by means of the statistical software SPSS 20 with the use of Student's t-test and Pearson's correlation.

\section{Results}

The aim of the first research stage was to detect whether there were any statistically significant differences between men and women in assessing the selected advertising perception attributes. However, the results of analyses did not confirm the existence of such differences between men and women in the assessment of the factors of advertising perception (Tables 1 and 2).

Table 1

Differences Between Men and Women in Assessing the Selected Advertising Perception Attributes

\begin{tabular}{lccc}
\hline & Cognition & Emotion & Behavior \\
\hline Mann-Whitney U test & 1140.50 & 1048.00 & 957.00 \\
$Z$ & -.05 & -.24 & -.75 \\
Asymp. Sig. (2-tailed) & .95 & .80 & .45 \\
\hline
\end{tabular}


Table 2

Median Values of Individual Factors of Advertising Perception

\begin{tabular}{lccc}
\hline Gender & Cognition & Emotion & Behavior \\
\hline Male & 2.14 & 1.57 & 1.22 \\
Female & 2.14 & 1.50 & 1.33 \\
Total & 2.14 & 1.57 & 1.33 \\
\hline
\end{tabular}

The acquired median values of all three factors can be specified in case of men and women on the side of varying degrees of disagreement with the response scale used. This is evidenced by the fact that both men and women have presented a very cautious approach in terms of cognitions, emotions, and their own behavior towards advertising. Due to these results, we have decided to conduct another research project on a larger sample, using more detailed methodologies.

The second research stage was therefore carried out on the second research sample. The links between the expectations of what an advertisement must contain for its recipients to become interested and the subjective perception of advertising were tested by the Pearson's correlation analysis. The results are shown in Table 3.

The examined indicators of expectations of advertising significantly correlated with perception of advertising. A high correlation coefficient (above 0.5) was recorded between expectations of strongly visual advertising and its perception of good visual and musical processing, and also humor and the element of surprise as well as between informative expectations and good music. Thus, it can be assumed that producers of ads should focus precisely on these aspects of advertising. Highly significant were also expectations of funny advertisement and perception of the element of surprise, then expectations of understandable advertising and perception of a good slogan or the element of surprise, and expectations of originality and perception of good visualization, or the element of surprise. Simultaneously, such correlation was also found between expectations of credibility and good musical processing.

Table 3

Correlations Between Expectations and Perception of Advertising - Recalculated Values

\begin{tabular}{|c|c|c|c|c|c|}
\hline Perception expectations & good slogan & good music & good visuals & humor & element of surprise \\
\hline true & $.340 * *$ & $.400 * *$ & $.214^{*}$ & .079 & $.239^{*}$ \\
\hline funny & $.451 * *$ & $.418 * *$ & $.298 * *$ & $.425 * *$ & $.560 * *$ \\
\hline understandable & $.530 * *$ & $.464 * *$ & $.436 * *$ & $.370 * *$ & $.525 * *$ \\
\hline credible & $.375 * *$ & $.505^{* *}$ & $.381 * *$ & $.262 * *$ & $.344 * *$ \\
\hline memorable & $.464 * *$ & $.494 * *$ & $.410^{* *}$ & $.350 * *$ & $.427 * *$ \\
\hline informative & $.457 * *$ & $.585 * *$ & $.514 * *$ & $.272 * *$ & $.315^{* *}$ \\
\hline unobtrusive & $.378 * *$ & $.303 * *$ & $.389 * *$ & $.323 * *$ & $.420 * *$ \\
\hline intelligent & $.456 * *$ & $.390 * *$ & $.430 * *$ & $.330 * *$ & $.434 * *$ \\
\hline genuine & $.420 * *$ & $.471 * *$ & $.533 * *$ & $.357 * *$ & $.516^{* *}$ \\
\hline visually stunning & $.481 * *$ & $.553 * *$ & $.581 * *$ & $.510 * *$ & $.555 * *$ \\
\hline artistic & $.368 * *$ & $.390 * *$ & $.405 * *$ & $.303 * *$ & $.272 * *$ \\
\hline
\end{tabular}

According to Table 3, there was no statistically significant correlation between expectations of truthfulness of advertising and humor (.079). Humor and truth in the presented results are not related to each other which, of course, could be discussed further. 
Examined gender differences in expectations of advertising were evaluated by running Student's t-test for two independent samples. The detected differences are presented in Table 4.

Table 4

Statistically Significant Differences in Expectations of Advertising in Terms of Gender

\begin{tabular}{|c|c|c|c|c|}
\hline Expectations of advertising & Gender & $M$ & $t$ & $p$ \\
\hline true & male & 3.83 & -.81 & .41 \\
\hline \multirow{2}{*}{ funny } & male & 4.11 & \multirow{2}{*}{-1.26} & \multirow[b]{2}{*}{.20} \\
\hline & female & 4.33 & & \\
\hline \multirow{2}{*}{ understandable } & male & 4.16 & \multirow{2}{*}{-2.25} & \multirow{2}{*}{.02} \\
\hline & female & 4.58 & & \\
\hline \multirow{2}{*}{ credible } & male & 3.89 & \multirow{2}{*}{-1.87} & \multirow{2}{*}{.06} \\
\hline & female & 4.25 & & \\
\hline \multirow{2}{*}{ memorable } & male & 3.73 & \multirow{2}{*}{-2.93} & \multirow{2}{*}{.004} \\
\hline & female & 4.27 & & \\
\hline \multirow{2}{*}{ informative } & male & 4.10 & \multirow{2}{*}{-2.55} & \multirow{2}{*}{.01} \\
\hline & female & 4.52 & & \\
\hline \multirow{2}{*}{ unobtrusive } & male & 3.90 & \multirow{2}{*}{-2.15} & \multirow{2}{*}{.03} \\
\hline & female & 4.30 & & \\
\hline \multirow{2}{*}{ intelligent } & male & 3.71 & \multirow{2}{*}{-2.57} & \multirow{2}{*}{.01} \\
\hline & female & 4.19 & & \\
\hline \multirow{2}{*}{ genuine } & male & 4.39 & \multirow{2}{*}{-3.14} & \multirow{2}{*}{.002} \\
\hline & female & 4.95 & & \\
\hline \multirow{2}{*}{ visually stunning } & male & 4.02 & \multirow{2}{*}{-3.56} & \multirow{2}{*}{.001} \\
\hline & female & 4.62 & & \\
\hline \multirow{2}{*}{ artistic } & male & 3.80 & \multirow{2}{*}{.19} & \multirow{2}{*}{.84} \\
\hline & female & 3.76 & & \\
\hline
\end{tabular}

Table 4 shows that the second research stage revealed certain statistically significant differences in expectations of advertising in terms of gender. The average values of the responses of women in the examined attributes of expectations of advertising (memorable, informative, intelligent, genuine, and visually stunning) are closer to the answers "mostly yes". These values are higher in contrast to men whose answers have lower average values and on the used response scale are between "yes" and "no". It means that in the examined attributes, women expect more advertising than men.

Examined gender differences in the perception of advertising were evaluated by Student's t-test for two independent samples. The detected differences are shown in Table 5.

Table 5

Statistically Significant Differences in Perception of Advertising in Terms of Gender

\begin{tabular}{lcccc}
\hline Perception of advertising & Gender & $M$ & $t$ & $p$ \\
\hline \multirow{2}{*}{ good slogan } & male & 4.20 & -3.31 & .001 \\
\hline \multirow{2}{*}{ good music } & female & 4.79 & -3.76 & .001 \\
\hline \multirow{2}{*}{ good visuals } & male & 4.29 & -2.33 & .02 \\
\hline \multirow{2}{*}{ humor } & $\begin{array}{c}\text { male } \\
\text { female }\end{array}$ & 4.88 & -2.58 & .01 \\
\hline \multirow{2}{*}{ element of surprise } & male & 4.76 & -3.99 & .001 \\
\hline
\end{tabular}

Table 5 presents the significant differences in the perception of advertising in terms of gender. The average values of the responses of women in the selected factors of perception of advertising (music, visuals, humor) are closer to the answers "mostly yes". Unlike men, whose average values of answers on the measurement scale used have reached the level 
"yes", these values are higher. Therefore, in perception of advertising, women prefer (and is more relevant to them) the musical and visual processing and humor more than men.

\section{Discussion and Conclusion}

Advertising is a paid form of communication between manufacturers and customers. People encounter it daily, it affects them and whether they want it or not, advertising is in their lives. The main objective of the research was to determine whether there is a statistically significant correlation between the expectations of advertising and perception of advertising in terms of gender specifics.

On the basis of the definition of gender issues related to the development of gender identities and strongly related to social and cultural significance (Cviková, Debrecínová, \& Kobová, 2007; Krook \& Childs, 2010), we assumed that the research as a whole would reveal statistically significant differences between men and women when assessing the selected advertising perception attributes. The first research stage results did not confirm this assumption. No significant differences between men and women were found in the advertising perception attributes.

Furthermore, the second research stage enabled specification of a large number of statistically significant correlations between the expectations of advertising and the subjective perception of advertising. In the specified context, no significant correlation between the expectations of the truthfulness of advertising and perception of humor in advertising was found. This finding suggests that the elements of humor in advertising must be carefully used especially in terms of the expectations of the truthfulness of advertising.

The research results confirm the suitability of the multidimensional theoretical and methodological reflection of the issue both on the level of expectations of advertising as well as on the perception of advertising.

In terms of gender, the results finally confirmed the differences between men and women in expectations of advertising as well as in the perception of advertising. Women have higher expectations of advertising than men and also perceive advertising more intensely. These findings correspond with the teachings of Statt (1977) who stated that women have more complex perception of advertising, while men interpret advertising by means of heuristic systems. The advertisement itself is experienced by women with a greater proportion of emotions than by men.

The identified and specified differences between men and women in terms of expectations of advertising and perception of advertising also correspond with the findings by Vysekalová and Mikeš (2010) who state that for a successful advertisement it is important to know the personality of its recipient and thus the gender specifics from the perspective of appropriate targeting of the ad at a certain group of people.

Finally, it should be noted that the acquired results related to the expectations of advertising and perception of advertising as trans-situational, dispositional traits of the ad receivers should be interpreted according to situational characteristics (Owolabi, 2005).

\section{Acknowledgements}

This research was conducted thanks to the support of the grant project VEGA 1/0909/16 (Research of determinants of decision-making in the business management and sales 
management, taking into account the personal and psychological aspects of trading, and analysis of the possible implications in neuromarketing).

\section{References}

Abrams, K., \& Keren, H. (1997). Who's afraid of law and the emotions? Minnesota Law Review, 94, 1997-2074.

Bačík, R., Fedorko, R., \& Bušová, S. (2012). Vybrané aspekty reklamy a jej vplyv na nákupné rozhodnutia spotrebitel’ov [Selected aspects of advertising and its influence on the buying behavior of consumers]. Hradec Králové: Magananimitas, $188-194$.

Barker, C. H. (2006). Slovník kulturálnich studii [Dictionary of cultural studies]. Praha: Portál.

Beck, A. T. Davis, D. D., \& Freeman, A (2007). Cognitive therapy of personality disorders. New York. Guilford Press.

Bovée, C. L., \& Arens, W. F. (1992). Contemporary advertising. 4th Ed. Illinois: Irwin Homewood. Casson.

Connell, R. W. (2002). Gender. Cambridge: Polity Press.

Cviková, J., Debrecéniová, J., \& Kobová, L'. (2007). Rodová rovnost’ [Gender equality], Bratislava: Občan a demokracia [online]. [acc.18-04-2015]. Retrieved from http://prison-education. oad.sk/sk/text4.pdf.

David, D., Lynn, S., \& Ellis, A. (2010). Rational and irrational beliefs: Implications for research, theory, and practice. New York: Oxford University Press.

Eckert, P., \& McConnell-Ginet, S. (2003). Language and gender. Cambridge: University Press.

Gail, D., \& Humez, J. M. (2003). Gender, race, and class in media: a text-reader. Thousand Oaks, CA. Sage Publications.

Istenik, P. (2011). Dunning-Krugger efekt-Chybné sebahodnotenie [Dunning-Krugger effect - defective self-evaluation; online]. [acc. 29-11-2014]. Available at: http://www.pouzimerozum.sk/2011/07/19/dunning-kruger-efekt-chybnesebahodnotenie/

Krook, M. L., \& Childs, S. (2010). Women, gender and politics. Oxford: Oxford university press.

Lelková, A., \& Lorincová, T. (2015). Analýza vplyvu reklamy na verejnost' [Analysis of the advertisement influence on the public]. Exclusive journal: Economy and Society and Environment, 3(3), 43-49.

Lindner, K. (2004). Images of women in general interest and fashion magazine advertisements from 1955 to 2002 . Sex Roles, 51, 409-421.

Mandel, D. R., Hilton, D. J., \& Catellani, P. (2005). The psychology of counterfactual thinking. London. Routledge.

McKay, N. J., \& Covell, K. (1997). The impact of women in advertisements on attitudes toward women. Sex Roles, 36 , 573-583.

Newell, A., \& Simon, H. A. (1972). Human problem solving. Englewood Cliffs, NJ: Prentice Hall.

Oakley, A. (1972). Sex, gender and society. London: Maurice Temple Smith Ltd.

Owolabi, A. (2005). Effects of gender-role orientation, sex of advert presenter and product type on advertising effectiveness. European Journal of Scientific Research, 35(4), 537-543.

Reifová, I. \& Kolektiv, N. (2004). Slovník mediální komunikace [Dictionary of media communication]. Praha: Portál.

Renzetti, C. M., Curran, D. J., \& Maier, S. L. (2012). Women, men, and society. Boston, MA: Pearson.

Seyffert, R. (1966). Werbelehre: theorie und praxis der werbung [Advertising theory: theory and practice of advertising]. Stuttgart: C. E. Poeschel, 1623-1642.

Stanton, W. J. (1984). Fundamentals of marketing. New York: McGraw-Hill.

Statt, D. A. (1977). Understanding the consumer - a psychological approach. London: Macmillan Press.

Suhányi, L., \& Suhányiová, A. (2014). Multi-criteria decision-making tool design for the investment decision-making of territorial self-government regions. Journal of applied economic sciences, 9(1), 110-122.

Štefko, R., Fedorko, R., \& Bačík, R. (2015). The role of e-marketing tools in constructing the image of a higher education institution. Procedia Social and Behavioral Sciences, 175, 431-438.

Toscani, O. (1996). Reklama je navoňaná zdochlina [Advertisement is scented carrion]. Bratislava: Slovart.

Vysekalová, J., \& Komárková, R. (2012). Psychologie reklamy, 3. vydanie [Psychology of advertising, $3^{\text {rd }}$ ed.]. Praha: Grada Publishing.

Vysekalová, J., \& Mikeš, J. (2010). Reklama: Jak dělat reklamu [Advertising: how to make an advertisement]. Praha. Grada Publishing.

Wharton, S. A. (2012). The sociology of gender: An introduction to theory and research. Oxford: John Wiley\&Sons Ltd. 